\title{
Over-confident and under-competent: exploring the importance of food safety education specific to high school students
}

\author{
Kenneth J. Diplock, ${ }^{* \dagger}$ Andria Jones-Bitton, ${ }^{*}$ Scott T. Leatherdale,* Steven Rebellato, ${ }^{\S}$ Joel A. Dubin, ${ }^{*, \|}$ and \\ Shannon E. Majowicz* \\ *School of Public Health and Health Systems, University of Waterloo, Waterloo, Ontario, Canada N2L $3 G 1$. \\ 'School of Health and Life Sciences and Community Services, Conestoga College Institute of Technology and Advance Learning, Kitchener, \\ Ontario, Canada N2G 4M4. \\ "Department of Population Medicine, University of Guelph, Guelph, Ontario, Canada N1G 2W1. \\ ${ }^{\S}$ Department of Clinical Epidemiology \& Biostatistics, McMaster University, Hamilton, Ontario, Canada L8S 4K1. \\ "Department of Statistics and Actuarial Science, University of Waterloo, Waterloo, Ontario, Canada N2L $3 G 1$.
}

\begin{abstract}
The objective of this study was to explore age-specific reasons why food safety education might be important for high school students (in Ontario, Canada), from a variety of expert perspectives. In May 2014, semi-structured key informant interviews $(n=20)$ were conducted with food safety and youth education experts. A thematic analysis of verbatim transcripts of the interviews was conducted. Participants identified three major reasons why food safety is important for high school students: (i) they have current and personal needs for food safety information, (ii) high school is an ideal time and place to instill life-long good habits, and (iii) they are part of the foodborne illness risk landscape. Food safety education was deemed important for high school students, who were seen as a unique and captive audience in need of safe food handling skills, now and in the future, for a variety of reasons: potential employment advantages, improved food literacy, combating their sense of "invincibility," and helping instill essential life skills that they may not get elsewhere. These results confirm the importance of food safety education for high school students and highlight the need to determine age-appropriate interventions and methods to engage high school students and improve their safe food handling practices.
\end{abstract}

Key words: food safety, education, high school, student, food handling.

Food safety education is an important part of foodborne disease prevention, and young people are an important demographic to target in North America. They often work in the food industry (Haapala and Probart, 2004; Usalcas, 2005; Yarrow et al., 2009) and are beginning to take greater responsibility for food handling (Burke and Dworkin, 2015). They also have low food safety knowledge (Abbot et al., 2009; Green and Knechtges, 2015; Haapala and Probart, 2004; Lynch et al., 2008; Majowicz et al., 2017; Pedigo et al., 2009; Quick et al., 2013; Richards et al., 2008; Yarrow et al., 2009), lack safe food handling experience and skills (Abbot et al., 2012; Haapala and Probart, 2004; Majowicz et al., 2017; Morrone and Rathbun, 2003; Nesbitt et al., 2009), and engage in risky food handling practices (Abbot et al., 2012; Altekruse et al., 1999; Haapala and Probart, 2004).

To date, research has predominantly assessed the food safety education needs of middle school (Byrd-Bredbenner et al., 2010; Lynch et al., 2008; Kim et al., 2012; Quick et al., 2013) and

Corresponding author: Shannon E. Majowicz (email: smajowicz@ uwaterloo.ca) college students (Abbot et al., 2012; Byrd-Bredbenner et al., 2008; Milton and Mullan, 2012; Mullan and Wong, 2010; Yarrow et al., 2009). High school students are another potentially important age group to target. They handle and prepare food for the public via work or volunteer positions (Majowicz et al., 2015), have low food safety knowledge, and report risky behaviours including tasting food to see if it is safe (Majowicz et al., 2015, 2017; Sanlier, 2009; Turconi et al., 2008). Given this age group may represent an important but overlooked demographic for primary prevention efforts via food safety education, the objective of this study was to explore age-specific reasons why food safety education might be important for high school students (in Ontario, Canada), from a variety of expert perspectives.

\section{Methods}

We used a phenomenological approach (Creswell, 2007) within a constructivist paradigm (Guba and Lincoln, 1994) to understand participants' perceptions of food safety needs and the 
factors influencing food safety knowledge and behaviours. Twenty semi-structured key informant interviews were conducted with professionals with expertise in food safety in the province of Ontario, food safety education in youth, or high school education in Ontario. Interviewees who had expertise in more than one area, or were familiar with food safety education in Ontario, were prioritized. Experts were identified via author lists from peer-reviewed literature, consultation with education and public health organizations, and snowball sampling (Merriam, 2009). We set out to conduct between 15 and 30 interviews, with approximately equal representation from public health professionals, educators, and food safety experts. Sampling continued until no new themes were identified (Morse et al., 2002). This study was approved through a University of Waterloo Research Ethics Committee.

A semi-structured interview guide (Supplementary Appendix $\mathrm{A}^{1}$ ) consisting of 10 open-ended questions, with prompts, was developed to probe for the importance of food safety knowledge, skills, and education in youth, and it was informed by question domains from previous youth food safety questionnaires (Byrd-Bredbenner et al., 2010; Yarrow et al., 2009). Participants were provided with Ontario's standardized food handler training document (Ministry of Health and Long Term Care (MOHLTC), 2013) as background material, and they were prompted throughout the interview to identify anything unique to high school students, including specific food safety risks or food handling behaviours. Telephone interviews were conducted between May and June 2014, and they were audio recorded. Interviews were designed to take approximately 45 minutes to complete. At the start of each interview, participants provided verbal informed consent.

Interviews were transcribed verbatim including all utterances (e.g., "er," "um"), anonymized, and corrected against the original audio recording, prior to analysis, with coding such as "[P1]" used to maintain participant confidentiality. For quotes reported here, utterances were removed, brackets were used to denote modifications, and tenses and omitted words were corrected using a denaturalized approach (Oliver et al., 2005). Interviews were analyzed using inductive thematic analysis (Braun and Clarke, 2006), facilitated by qualitative research software (ATLAS.ti, version 7.5.6; Cincom Systems, Inc., (C2015). Codes were iteratively derived from the interview data as per Fereday and Muir-Cochrane (2006) as follows. First, three researchers independently reviewed five transcripts and developed a preliminary list of codes. Preliminary codes were collated into a codebook containing the draft codes, working definitions, and explanatory quotes. The codebook was revised by the three researchers in concert until it accurately captured the content of the five interviews. This revised codebook was then used by one researcher to code all transcripts, and it was iteratively refined during coding, such that the final codebook represented the content and meaning of all interviews. Final codes were then grouped into themes. Themes were iteratively refined until they clearly represented the fundamental theme of the grouped codes. Finally, themes and codes were reviewed again, by all three researchers, to ensure they corroborated the data from the interviews. Memos were used throughout

${ }^{1}$ Supplementary data are available with the article through the journal Web site at http://pubs.ciphi.ca/doi/full/10.5864/d2017-018. the analysis to capture and detail decisions related to operational research steps, categorization of data, and exploration of relationships within the data (Birks et al., 2008). Standard techniques to enhance credibility of the findings were used, including audit trail, multiple coding, disconfirming evidence, and inclusion of deviant cases (Green and Thorogood, 2005).

\section{Results}

Participants were predominantly female $(n=15)$, the majority worked in Ontario $(n=18)$, and all had at least 10 years' experience in their identified areas of expertise. Participants were educators $(n=7)$, food safety experts $(n=6)$, or public health professionals $(n=7)$. Of the seven educators, six taught hospitality, food, and nutrition-related courses at the high school $(n=$ $3)$ and college $(n=3)$ levels, and one was a professional food safety educator. Of the six food safety experts, two were university researchers; two worked in food, food safety, and nutrition policy; and two were home economists. Of the seven public health professionals, four were certified Public Health Inspectors, one was a public health manager, one was a public health specialist, and one was a health promoter.

Universally, participants spoke about the importance of food safety education for high school students, because: $(i)$ they have current and personal needs for food safety information, (ii) high school is an ideal time and place to instill life-long good food safety habits, and (iii) they are part of the foodborne illness risk landscape (Tables 1-3). The codes underpinning these three major themes are described below and in Tables 1-3, and encapsulate constructs related to individual advantage and personal protection, population-level benefit of having food handlers trained to prevent foodborne illness, students' low food literacy levels, and a lack of good food handling role models. Further, participants described how these reasons, and their underlying factors, happen concurrently rather than independently, creating "a perfect storm" [P4] of factors that amplifies the need for education. Generally, participants were in agreement regardless of their background or area of expertise.

\section{Personal need for food safety education}

Students' current and personal need for food safety education (Table 1) arose from their involvement in food preparation at home, at school, and while travelling for sports and other activities, as well as via working in the food industry. All participants viewed food safety as not only a marketable job skill, but also an essential life skill. Participants saw food safety education as offering students an employment advantage because the food industry is a common student employment area (e.g., "I could say that there are companies now that would...look at (students) having a food handler certification as a(n) employment advantage" [P15]).

Food safety was also seen as an important life skill, in part due to students' increasing responsibility for handling and preparing food for themselves ("students increasingly, as it gets towards graduation and beyond, they are being forced to take a more active role in food prep in the home, and they're not necessarily aware how to do it safely and cheaply" [P6]), and others, ("it's an important life skill, to apply later in life to protect (themselves) and (their) family members and any friends [they're] serving food to in a private 
Table 1. Codes and exemplar quotes under the theme "high school students have current and personal needs for food safety information," derived from key informant interviews of 20 food safety and youth education experts (May-June, 2014)

\begin{tabular}{|l|l|l|}
\hline Code & \multicolumn{1}{|c|}{ Code description } & \multicolumn{1}{c|}{ Exemplar quote } \\
\hline $\begin{array}{l}\text { Food safety } \\
\text { education is an } \\
\text { employment } \\
\text { advantage }\end{array}$ & $\begin{array}{l}\text { Food safety education can offer an employment } \\
\text { advantage for high school students. If they become a } \\
\text { certified food handler, they may be a more valuable } \\
\text { potential employee in the food industry, a common } \\
\text { source of employment for students. }\end{array}$ & $\begin{array}{l}\text { "So for them, they're wanting to get the [food safety } \\
\text { training] certificate, as kind of a 'foot in the door', to } \\
\text { make them look better than the other applicants..." } \\
\text { [P2] }\end{array}$ \\
\hline $\begin{array}{l}\text { They have a } \\
\text { current need to } \\
\text { prepare food } \\
\text { safely }\end{array}$ & $\begin{array}{l}\text { High school students currently need to prepare food } \\
\text { safely for themselves and others, including (a) family } \\
\text { and friends, and (b) customers (if youth are working in } \\
\text { the food industry). }\end{array}$ & $\begin{array}{l}\text { "So they would be the first one home, and so they } \\
\text { would be responsible for making meals." [P18] }\end{array}$ \\
\hline $\begin{array}{l}\text { They are "food } \\
\text { illiterate" }\end{array}$ & $\begin{array}{l}\text { High school students are not food literate: they do not } \\
\text { have the food skills to choose and prepare healthy, } \\
\text { safe, and nutritious meals. Also, reading and under- } \\
\text { standing food labels and cooking instructions is an } \\
\text { issue for students. }\end{array}$ & $\begin{array}{l}\text { "Because unfortunately, we're getting to be a bunch of } \\
\text { 'food illiterates' in society. Where not only do we not } \\
\text { know how to cook properly, but when we do finally } \\
\text { cook...if it's not reheated in the microwave, we're not } \\
\text { sure exactly what to do with it." [P2] }\end{array}$ \\
\hline $\begin{array}{l}\text { They lack good } \\
\text { role models } \\
\text { for safe food } \\
\text { handling }\end{array}$ & $\begin{array}{l}\text { High school students often lack good role models } \\
\text { when it comes to food safety and safe food handling } \\
\text { behaviours. There is less passing down of "traditional" } \\
\text { cooking skills in the home setting due to changes in } \\
\text { family dynamics, increased eating out, and reliance } \\
\text { on pre-packaged foods. Some of the skills and advice } \\
\text { being passed down may be incorrect (e.g., thawing } \\
\text { food on the counter or in the sink overnight). }\end{array}$ & $\begin{array}{l}\text { "... think people have gotten away from home } \\
\text { cooking a little bit, and maybe some of the practical } \\
\text { experience in handling food, that they may not have } \\
\text { had passed down from their parents..." [P15] }\end{array}$ \\
\hline
\end{tabular}

Table 2. Codes and exemplar quotes under the theme "high school is an ideal time and place to instill life-long good habits," derived from key informant interviews of 20 food safety and youth education experts (May-June, 2014)

\begin{tabular}{|c|c|c|}
\hline Code & Code description & Exemplar \\
\hline $\begin{array}{l}\text { They are devel- } \\
\text { oping life skills } \\
\text { in preparation for } \\
\text { living on their } \\
\text { own }\end{array}$ & $\begin{array}{l}\text { High school students are developing life skills (e.g., } \\
\text { budgeting and cooking) in high school, and safe food } \\
\text { handling is one of the skills that should be developed in } \\
\text { students. }\end{array}$ & $\begin{array}{l}\text { "I think it should be offered absolutely, probably, } \\
\text { cooking skills, and budget skills, and other, you } \\
\text { know, life skills... doing your taxes - you know, a } \\
\text { whole bunch of things that you're not really taught } \\
\text { from an academic stand point." [P6] }\end{array}$ \\
\hline $\begin{array}{l}\text { Food safety } \\
\text { knowledge and } \\
\text { skills are trans- } \\
\text { ferable from } \\
\text { students to others }\end{array}$ & $\begin{array}{l}\text { Food safety knowledge and good food safety skills can } \\
\text { be transferred immediately, and in the future, to life } \\
\text { outside the classroom. For example, skills can be trans- } \\
\text { ferred to parents and siblings at home or to workplace } \\
\text { colleagues if the student is working in the food industry. } \\
\text { In future, skills can be transferred to those being cared } \\
\text { for, including children and the elderly. }\end{array}$ & $\begin{array}{l}\text { "I had a situation (in) a parent-teacher interview, } \\
\text { a parent actually said something about how that } \\
\text { message had come home, when the student in my } \\
\text { class was watching her sister getting some chicken } \\
\text { ready for a family meal... and reminding the sister } \\
\text { what she should be doing and not doing in terms of } \\
\text { chicken... so thinking about the transferability that } \\
\text { can happen; that was a positive thing." [P12] }\end{array}$ \\
\hline $\begin{array}{l}\text { Students' food } \\
\text { handling re- } \\
\text { sponsibilities } \\
\text { are undergoing } \\
\text { a transition from } \\
\text { passive ob- } \\
\text { server to active } \\
\text { participant }\end{array}$ & $\begin{array}{l}\text { High school students are expanding their food han- } \\
\text { dling roles and responsibilities, from nonparticipant, } \\
\text { to observer, to helper, to preparer. They are, or will be, } \\
\text { transitioning from simple (e.g., bowl of cereal, making a } \\
\text { sandwich), to moderate (e.g., reheating leftovers, cook- } \\
\text { ing using a microwave), and possibly to complex meal } \\
\text { preparation (e.g., full meals, cooking raw meats). They } \\
\text { will also eventually have expanded responsibilities for } \\
\text { selecting and purchasing of food. }\end{array}$ & $\begin{array}{l}\text { "Food safety I think is very important for lots of } \\
\text { reasons. One is they are preparing more and more } \\
\text { foods themselves, and families are giving them more } \\
\text { and more responsibilities, and very soon after they } \\
\text { get out of secondary education, many of them are } \\
\text { going to be... living independently and are going to } \\
\text { have responsibility for (food handling) in their own } \\
\text { homes, or apartments or dorms or wherever they } \\
\text { happen to be living..." [P14] }\end{array}$ \\
\hline $\begin{array}{l}\text { High school stu- } \\
\text { dents are a "cap- } \\
\text { tive audience" }\end{array}$ & $\begin{array}{l}\text { Youth are required to attend and participate in high } \\
\text { school courses. Material offered in mandatory courses } \\
\text { reaches most, if not all, youth in high school. After high } \\
\text { school or outside the classroom it is much harder to effec- } \\
\text { tively deliver food safety education messages to youth. }\end{array}$ & $\begin{array}{l}\text { "...it is an ideal opportunity to reach them. Once } \\
\text { they leave high school, unless they go to college- } \\
\text { and even in college it is kind of hard to reach } \\
\text { them--but they are a captive audience in secondary } \\
\text { school." [P14] }\end{array}$ \\
\hline
\end{tabular}


Table 3. Codes and exemplar quotes under the theme "high school students are part of the foodborne illness risk landscape," derived from key informant interviews of 20 food safety and youth education experts (May-June, 2014)

\begin{tabular}{|c|c|c|}
\hline Code & Code description & Exemplar quote \\
\hline $\begin{array}{l}\text { They pose a risk to } \\
\text { their future selves }\end{array}$ & $\begin{array}{l}\text { In future, because of changing behaviours and } \\
\text { immune status, they will be at risk for foodborne } \\
\text { illness and other health issues related to poor food } \\
\text { handling. }\end{array}$ & $\begin{array}{l}\text { "Young males... who haven't cooked and they make } \\
\text { all these mistakes and may get food poisoning, and } \\
\text { we did see that with higher Campylobacter rates } \\
\text { in university male students, so even though their } \\
\text { immune systems are pretty strong, we're still seeing } \\
\text { cases emerge in that group." [P4] }\end{array}$ \\
\hline $\begin{array}{l}\text { They pose a risk to } \\
\text { others, now and in the } \\
\text { future }\end{array}$ & $\begin{array}{l}\text { High school students pose a current and future } \\
\text { risk to others, e.g., family and friends, if they are } \\
\text { preparing and sharing food and to customers if they } \\
\text { work in the food industry. }\end{array}$ & $\begin{array}{l}\text { "Many of them will have children and we know that } \\
\text { children... have reduced ability to resist foodborne } \\
\text { infections... These kids are going to grow up at } \\
\text { some point and probably be taking care of their } \\
\text { own parents, and we know that elderly folks have } \\
\text { a greater risk of really succumbing to some of the } \\
\text { more severe effects of foodborne illness." [P14] }\end{array}$ \\
\hline $\begin{array}{l}\text { They take more risks } \\
\text { because, it's "not going } \\
\text { to happen to me" }\end{array}$ & $\begin{array}{l}\text { High school students engage in riskier behaviours, } \\
\text { because they have a skewed perception of the risks } \\
\text { associated with food and foodborne illness, due to } \\
\text { adolescent life stage, egocentricity, sense of invinci- } \\
\text { bility, and poor risk evaluation skills. }\end{array}$ & $\begin{array}{l}\text { "I think you will find that teens are, take more risks, } \\
\text { because of this, in this focus on not being vulnera- } \\
\text { ble to those risks, like it is 'not going to happen to } \\
\text { me'." [P6] }\end{array}$ \\
\hline $\begin{array}{l}\text { They consume conve- } \\
\text { nience meals but do not } \\
\text { realize some of these } \\
\text { products need to be } \\
\text { fully cooked }\end{array}$ & $\begin{array}{l}\text { High school students handle, prepare, and eat a } \\
\text { large amount of meals that have, or can be per- } \\
\text { ceived to have, few or no preparation steps (e.g. } \\
\text { microwave meals, leftovers, take out, prepackaged } \\
\text { foods). These meals, marketed to youth, are conve- } \\
\text { nient for them to prepare (no or very few prepara- } \\
\text { tion steps), and easy to take and go. These meals } \\
\text { often contain specific preparation directions (e.g., } \\
\text { cook, reheat, refrigerate immediately) that need to } \\
\text { be followed to keep the food safe. }\end{array}$ & $\begin{array}{l}\text { "There have been cases where kids are maybe } \\
\text { taking chicken nuggets and things like that, and } \\
\text { cooking them in the microwave just so they're hot } \\
\text { enough, but really when they are not fully cooked } \\
\text { product, that's not appropriate." [P11] }\end{array}$ \\
\hline
\end{tabular}

setting" [P7]). Students' imminent departure from home (e.g., to pursue post-secondary education or to live on their own) and current or future roles in caring for kids and elderly parents were also given as reasons education is important.

Participants talked about the importance of building general food literacy among high school students, in part "because we're finding that food literacy is really low in young adults" [P8], and because,

I think more and more, nowadays we are seeing a real shift in culture into the fast food business... and more and more people not having the basic skill set to be able to prepare, healthy, nutritious food at home, and I think by making people aware of how to do that, that opens up another set of possibilities. [P19]

Participants also discussed home-based, negative influences on food literacy, including students rarely being involved in grocery shopping and cooking, and a lack of good food safety role models from whom to learn knowledge and skills (e.g., "...young people are not getting a lot of the basic food skills and 'food literacy' understanding from their parents" [P16]).

\section{Ideal time and place for food safety education}

High school was seen as an ideal time and place to instill safe food handling life skills (Table 2; e.g., "as a youth, they're developing life skills and, preparing food, eating food, and it keeps them healthy and vital so they can be active in their academics and active with their community and athletic endeavours" [P5]), because "...they are going to need these skills for the rest of their lives" [P14]. Food safety skills learned by high school students were seen as transferable to other people: "they probably could go home and (teach) their parents some things" [P15], and "a lot of it's common sense, and things that they can use in their home life as well; so, it is very applicable to everyone" [P16].

High school was also discussed as an ideal time and place because "(food safety) is knowledge that is appropriately aged for them..." [P18], and because of students' transitioning food handling responsibilities from passive observer to active participant. Students were also seen as a captive audience due to high school's required attendance, so that high school "is an ideal opportunity to make sure that we are, I don't know- vaccinating' them or 'inoculating' them with this knowledge-and we can do it in a very systematic way, because of the way that secondary (education) is set up versus post-secondary education" [P14]. These views connected with thoughts expressed by Public Health Inspector participants who indicated that more high schools are requesting food safety information and training.

Participants connected food safety education within high schools to nutrition education, both within courses (e.g., "so I think in teaching nutrition, you are also teaching food safety, so that, people understand how to keep themselves safe" [P19]), 
and athletics (e.g., "one of the big problems that these kids have is buying food ahead of time to eat on the bus, to get to where they are going, and it is not refrigerated" [P14]). Participants suggested a unique opportunity to deliver education may be to connect with athletic coaches to incorporate food safety messages and practices into their nutrition discussions:

\begin{abstract}
I think there are, would be opportunities to coach and enhance these food handler skills or these life, food-related life skills, with our sports groups, because they talk about nutrition and sport nutrition, and looking after themselves, and being vital and, you could incorporate, weave, that information into that type of an opportunity. [P5]
\end{abstract}

Despite widespread support for including food safety education in high schools, two significant challenges were discussed: it is difficult to change curriculum and food safety in Ontario high schools is currently only taught in elective courses. As stated by one participant,

...foods and nutrition kind of programing would definitely be covered off, but
typically that kind of course is more of an elective, it's not a core course, and so
not every bigh school student would be receiving that kind of education. [P8]

\section{High school students are part of the risk landscape}

Participants saw high school students as part of the wider foodborne illness risk landscape including being both a risk to their future selves and others (Table 3), as one participant stated,

\begin{abstract}
There is a reasonable suspicion, or evidence, that would suggest that most episodes of foodborne illness are related to preparation in private or home settings as opposed to commercial establishments, and I think, by reaching people in high school, and training them in proper food safety, we can improve the food safety skills of the next generation of private home food preparers.... [P7]
\end{abstract}

Participants commented that students tend to take more risks, while being unaware of $(i)$ how food mishandling can lead to foodborne illnesses, and (ii) people's susceptibility to, and the potentially severe consequences of, foodborne illness. Further, most noted the importance of food safety education to combat students' sense of invincibility or it is "not going to happen to me" [P6]. One participant expressed these concepts, stating,

I have (extended family members) who are entering that phase (high school) and they-I would classify them as over-confident, under-competent in some areas, and, maybe some of their decision making hasn't fully developed, so that they understand the consequences of their actions. [P5]

Participants also noted that students handle, prepare, and consume large amounts of "convenience" foods (i.e., those that have few or no preparation steps like microwave meals, prepackaged snacks, take-out), putting them at risk for foodborne disease. As stated by one participant,

in several outbreaks, which frozen food, so chicken nuggets, even frozen hamburgers too...the stuff that they think are already cooked. It's really important to be looking at your packaging to see how you need to prepare $i t$, so whether using the oven, whether using a microwave, which most people tend to do to do it quickly, you need to verify your, your preparation steps, and the temperature that goes along with that. [P7]

Finally, participants discussed the many reasons and themes presented above as co-occurring in a variety of ways, and that the co-occurrence of these factors amplifies the need for education. One participant epitomized this confluence as follows:

So we have a 'perfect storm' of low food literacy with teenagers, who are now cooking to feed the growing seniors, the demographic is increasing in the seniorpopulation, elderly and immuno-compromised. That is a perfect storm. You want to be able to take care of that, with training and information to help them as they cook within their homes and occupations as well. [P4]

\section{Discussion}

Using interviews with 20 food safety and youth education experts, three overarching reasons for food safety education being important for high school students were identified: $(i)$ they have current and personal needs for the information, (ii) the high school environment offers an ideal time and place to instill good food safety habits, and (iii) despite falling outside of the traditional high-risk groups, youth are indeed part of the foodborne illness risk landscape. Further, the "perfect storm" [P4] of students' personal food safety needs, low food literacy levels, and poor food handling practices, was seen as amplifying the need for education in this demographic.

Broadly, these findings are consistent with the literature on middle school and college aged individuals, who also have low food literacy and poor food safety knowledge (Abbot et al., 2009; Green and Knechtges, 2015; Haapala and Probart, 2004; Lynch et al., 2008; Pedigo et al., 2009; Quick et al., 2013; Richards et al., 2008; Yarrow et al., 2009), limited food handling experience and skills (Abbot et al., 2012; Haapala and Probart, 2004; Morrone and Rathbun, 2003; Nesbitt et al., 2009), and who regularly engage in risky food handling practices and eating behaviours (Abbot et al., 2012; Altekruse et al., 1999; ByrdBredbenner et al., 2008; Haapala and Probart, 2004; Nesbitt et al., 2009; Patil et al., 2005). Although differences in study times and populations preclude specific comparisons, our findings from high school students may suggest that such factors may remain relatively unchanged across the middle school to college years.

Here, participants discussed how high school students are at an age of transition in food handling responsibilities; this finding was expected given that food handling responsibility appears to shift with age, from helping make meals and snacks in middle school (Haapala and Probart, 2004; Pedigo et al., 2009), to being solely responsible for food preparation in college (Green and Knechtges, 2015). Determining the ages at which young people take on particular responsibilities (e.g., helping to make meals, grocery shopping, making their own snacks or meals) is needed to help target safe food handling messages specific to age-relevant preparation steps and handling experiences. For example, participants discussed students' preparation and consumption of "convenience" foods as an important potential risk. The range of convenience foods available removes the need for developing basic cooking skills (Caraher and Lang, 1999), and outbreaks from convenience foods, including pre-made chicken quesadillas (Centers for Disease Control and Prevention (CDC), 2013) and cookie dough (Neil et al., 2012), have disproportionately impacted young people versus other ages. Thus, age-specific food safety education for high school students should teach them specifically how to safely prepare and consume these and other foods commonly consumed in this age group. 
Participants identified food safety education for students as important, beyond simply providing a marketable and important job skill for those interested in the food industry. A main identified impetus for education was students' lack of good food handling role models, stemming from lack of knowledge and skill transfer from parents, who may follow unsafe practices, as well as students rarely being involved in meal preparation. Indeed, food skills and nutrition knowledge in young people have diminished in recent years due to decreased food skills home mentoring (Slater, 2013) and lack of exposure to food and food handling, often because of parents taking over and carrying out food work on their own without involving others (Beagan et al., 2008; Larson et al., 2006). Given that food safety knowledge and practices of consumers in general are often inadequate and inconsistent (Milton and Mullan, 2010; Patil et al., 2005), the danger of youth inadvertently learning unsafe practices exists. Fortunately, a food-based school curriculum can offset food handling deficiencies learned elsewhere (Höijer et al., 2011), further supporting the argument for food safety education in school settings.

High school was identified as an ideal time and place to instill life-long good food safety habits, in part because students' required attendance makes them a "captive audience." Food safety education directed at students was seen as a mechanism for widespread "inoculation" of safe food handling practices, thereby combatting low food literacy, risky food handling practices, and lack of good food handling mentors in the home. However, an important identified barrier was that, in Ontario, food safety education is only found in elective Food and Nutrition courses (Ontario Ministry of Education, 2013), and thus only reaches a subset of students. Home economic, food, and nutrition courses are essential for developing important life skills, including food preparation and hygiene (Shearer et al., 2014; Slater, 2013), and including cooking skills in curricula is important to prepare individuals to be able to implement healthy food choices (Caraher and Lang, 1999). However, nutrition and home economics classes are becoming less common (ByrdBredbenner et al., 2013), and many young people opt not to enroll in such electives (Yarrow et al., 2009). Enrollment appears to decline with age, from $45 \%$ of grade seven students, to $7.6 \%$ of grade 12 students, and many administrators, non-home economics teachers, and parents do not value such courses (Slater, 2013). Thus, relying on elective curricula to deliver food safety education is likely insufficient. In addition to supporting food safety education in Food and Nutrition courses (e.g., via providing materials or guest lectures), public health professionals should seek other avenues for educating students, such as advocating for mandatory food safety education for all students and engaging athletic coaches to include food safety in their nutrition advices as identified here.

An additional advantage of wider food safety education for students in high schools is that, as suggested here, knowledge and skills can be transferred to parents and others at home. In general, young people equipped with food and nutrition education can play an important role in improving not only their health, but also the health of their families (Caraher and Lang, 1999). However, the transferability of food safety skills per se has not been explicitly demonstrated and whether food safety education offers tangible benefits for others in the household should be assessed.
This study identified students as an important part of the foodborne illness risk landscape, in part because of their general sense of invincibility, a factor not limited to youth; Redmond and Griffith (2004) identified "optimistic-bias" and "illusion of control" as key factors in consumers' perceptions of invulnerability to illness from self-prepared food. Here, all participants but one felt students lacked an understanding of risks and personal susceptibility to foodborne illness. Perceptions of susceptibility to foodborne illness appear to vary by age; middle school students report strong feelings of susceptibility (ByrdBredbenner et al., 2010), approximately half of high school students report concern about getting foodborne illness (Majowicz et al., 2015), and most undergraduate students report feeling not overly at risk of foodborne illness (Green and Knetchges, 2015). Interestingly, a recent study of Ontario high school students found their concern about foodborne illness did not change following food safety education (Majowicz et al., 2017), such that the role of food safety education in influencing perceptions of susceptibility remains unclear.

Students' sense of invincibility and risky food handling practices may stem from their developmental stage, where asynchronous development of the adolescent brain results in increased risk-taking (Smith et al., 2013) and from psychosocial factors linked to poor food safety behaviours, including low perceived behavioural control (Mullan and Wong, 2010; Mullan et al., 2015), low perceived susceptibility (Haapala and Probart, 2004), and learned habits (i.e., past behaviours; Byrd-Bredbenner et al., 2010; Chow and Mullan, 2010; Haapala and Probart, 2004). Since successfully changing risky food handling behaviours is predicated on feeling susceptible to illness, having incentives to take action, and feeling competent to carry out appropriate actions (Schafer et al., 1993), further research investigating psychological factors and how they can influence students' food safety behaviours is needed.

The main limitation of the findings presented here is that participants were experts in food safety or youth education. Parents and students may have different perspectives about the importance of food safety education than those reported here. Including student and parent perspectives in future will further our understanding of youth-specific food safety education needs, particularly around topics for which they might be most receptive. Generalizability is not a goal of qualitative research; nevertheless, readers may want to note that study participants may not be representative of all educators, experts, and public health professionals given the sampling approach and size.

\section{Conclusion}

High school students are a unique and captive audience in need of safe food handling skills to reduce both current and future risk. Food safety education for this demographic is important; beyond offering an employment advantage, it is needed by all students to improve food literacy and instill essential life skills that may not be cultivated at home. However, relying on existing curriculum to deliver food safety education will not reach all students. Thus, public health professionals should seek other avenues for education (e.g., engaging athletic coaches, providing student specific food safety messages), and advocating for mandatory food safety education in high schools. 


\section{Acknowledgements}

The authors thank the Ontario Ministry of Health and Longterm Care for providing the provincial standard food handler training material; Dr. Andrew Papadopoulos (Dept. of Population Medicine, University of Guelph) for helping develop the interview guide and for providing early input on the overall project; and Dr. David Hammond (School of Public Health and Health Systems, University of Waterloo) for early comments on the draft manuscript.

The research was funded by the Ontario Ministry of Agriculture, Food and Rural Affairs' Food Safety Research Program (FS2013-1843; grant awarded to S. Majowicz). The research built off an existing research platform (COMPASS) supported by a bridge grant from the Canadian Institutes of Health Research (CIHR) Institute of Nutrition, Metabolism and Diabetes through the "Obesity - Interventions to Prevent or Treat" priority funding awards (OOP-110788; grant awarded to $S$. Leatherdale) and an operating grant from the CIHR Institute of Population and Public Health (MOP-114875; grant awarded to $S$. Leatherdale). Additional support was provided via CIHR Public Health Agency of Canada Chair in Applied Public Health (S. Leatherdale).

\section{References}

Abbot, J. M., Byrd-Bredbenner, C., Shaffner, D., Bruhn, C.M., and Blalock, L. 2009. Comparison of food safety cognitions and self-reported food-handling behaviours with observed food safety behaviours of young adults. Eur. J. Clin. Nutr. 63: 572-579. doi: $10.1038 /$ sj.ejcn.1602961

Abbot, J. M., Policastro, P., Bruhn, C., Schaffner, D.W., and ByrdBredbenner, C. 2012. Development and evaluation of a university campus-based food safety media campaign for young adults. J. Food Prot. 75: 1117-1124. doi: 10.4315/0362-028X.JFP-11-506

Altekruse, S. F., Yang, S., Timbo, B. B., and Angulo, F. J. 1999. A multi-state survey of consumer food-handling and foodconsumption practices. Am. J. Prev. Med. 16: 216-221. doi: 10.1016/S0749-3797(98)00099-3

Beagan, B., Chapman, G. E., D’Sylva, A., and Bassett, B. R. 2008. 'It's just easier for me to do it:': Rationalizing the family division of foodwork. Sociology. 42: 653-671. doi: 10.1177/0038038508091621

Birks, M., Chapman, Y., and Francis, K. 2008. Memoing in qualitative research probing data and processes. J. Res. Nurs. 13: 68-75. doi: $10.1177 / 1744987107081254$

Braun, V., and Clarke, V. 2006. Using thematic analysis in psychology. Qual. Res. Psychol. 3: 77-101. doi: 10.1191/1478088706qp063oa

Burke, A., and Dworkin, M. 2015. How knowledgeable are high school students about food safety? Results from a predominantly minority Chicago charter school. Brit. Food J. 117: 1737-1752. doi: 10.1108/BFJ-07-2014-0277

Byrd-Bredbenner, C., Abbot, J. M., and Quick, V. 2010. Food safety knowledge and beliefs of middle school children: Implications for food safety educators: Research in food science education. J. Food Sci. Educ. 9: 19-30. doi: 10.1111/j.1541-4329.2009.00088.x

Byrd-Bredbenner, C., Abbot, J. M., Wheatley, V., Schaffner, D., Bruhn, C., and Blalock, L. 2008. Risky eating behaviors of young adultsimplications for food safety education. J. Am. Diet. Assoc. 108: 549-552. doi: 10.1016/j.jada.2007.12.013
Byrd-Bredbenner, C., Berning, J., Martin-Biggers, J., and Quick, V. 2013. Food safety in home kitchens: A synthesis of the literature. Int. J. Environ. Res. Publ. Health. 10: 4060-4085. doi: 10.3390/ijerph 10094060

Caraher, M., and Lang, T. 1999. Can't cook, won't cook: A review of cooking skills and their relevance to health promotion. Int. J. Health Promot.Educ. 37: 89-100.doi: 10.1080/14635240.1999.10806104

Centers for Disease Control and Prevention (CDC). 2013. Multistate outbreak of Shiga toxin-producing Escherichia coli O121 infections linked to farm rich brand frozen food products (final update). Available at: http://www.cdc.gov/ecoli/2013/O121-03-13/. (Accessed 15 August 2017.).

Chow, S., and Mullan, B. 2010. Predicting food hygiene. An investigation of social factors and past behaviour in an extended model of the health action process approach. Appetite. 54: 126-133. doi: 10.1016/j.appet.2009.09.018

Creswell, J. W. 2007. Qualitative inquiry \& research design: Choosing among five approaches. Sage, Thousand Oaks, CA.

Fereday, J., and Muir-Cochrane, E. 2006. Demonstrating rigor using thematic analysis: A hybrid approach of inductive and deductive coding and theme development. Int. J. Qual. Methods. 5: 80-92. doi: $10.1177 / 160940690600500107$

Green, E. J., and Knechtges, P. L. 2015. Food safety knowledge and practices of young adults. J. Environ. Health. 77: 18-24.

Green, J., and Thorogood, N. 2005. Qualitative methods for health research. Sage, Thousand Oaks, CA.

Guba, E., and Lincoln, Y. 1994. Handbook of qualitative research. Sage, Thousand Oaks, CA.

Haapala, I., and Probart, C. 2004. Food safety knowledge, perceptions, and behaviors among middle school students. J. Nutr. Educ. Behav. 36: 71-76. doi: 10.1016/S1499-4046(06)60136-X

Höijer, K., Hjälmeskog, K., and Fjellström, C. 2011. 'Food with a purpose' - Home economics teachers' construction of food and home. Int. J. Consum. Stud. 35: 514-519. doi: 10.1111/j.1470-6431.2011.01014.x

Kim, E.J., Pai, A.J., Kang, N., Kim, W.K., Kim, Y.S., Moon, H. and Ha, A.W. 2012. The effect of food safety education on adolescents' hand hygiene behavior: an analysis of stages of change. Nutr. Res. Pract. 6(1), 169-174. https://doi.org/10.4162/nrp.2012.6.2.169

Larson, N. I., Story, M., Eisenberg, M. E., and Neumark-Sztaine, D. 2006. Food preparation and purchasing roles among adolescents: Associations with sociodemographic characteristics and diet quality. J. Am. Diet. Assoc. 106: 211-218. doi: 10.1016/j.jada.2005.10.029

Lynch, R. A., Steen, M. D., Pritchard, T. J., Buzzell, P. R., and Pintauro, S. J. 2008. Delivering food safety education to middle school students using a web-based, interactive, multimedia, computer program. J. Food Sci. Educ. 7: 35-42. doi: 10.1111/j.1541-4329.2007.00046.x

Majowicz, S. E., Diplock, K. J., Leatherdale, S. T., Bredin, C. T., Rebellato, S., Hammond, D., Jones-Bitton, A., and Dubin, J. A. 2015. Food safety knowledge, attitudes, and self-reported practices among Ontario high school students. Can. J. Public Health. 106: E520. doi: 10.1016/j.foodcont.2017.01.011

Majowicz, S. E., Hammond, D., Dubin, J. A., Diplock, K. J., JonesBitton, A., Rebellato, S., and Leatherdale, S. T. 2017. A longitudinal evaluation of food safety knowledge and attitudes among Ontario high school students following a food handler training program. Food Cont. 76: 108-116.

Merriam, S. B. 2009. The design of qualitative research. In Qualitative research. Wiley, San Francisco, CA, pp. 78-79. 
Milton, A., and Mullan, B. 2010. Consumer food safety education for the domestic environment: A systematic review. Br. Food J. 112: 1003-1022. doi: 10.1108/00070701011074363

Milton, A. C., and Mullan, B. A. 2012. An application of the theory of planned behavior - A randomized controlled food safety pilot intervention for young adults. Health Psychol. 31(2): 250-259. doi: $10.1037 / \mathrm{a} 0025852$

Ministry of Education. 2013. The Ontario curriculum grade 9 to 12: Social Sciences and Humanities. Available at: http://www.edu.gov. on.ca/eng/curriculum/secondary/sstudies.html [accessed 09 May 2016].

Ministry of Health and Long Term Care (MOHLTC). 2013. Food safety: A guide for Ontario's food handlers. Queen's Printer for Ontario, Toronto, Ontario.

Morrone, M., and Rathbun, A. 2003. Health education and food safety behavior in the university setting. J. Environ. Health. 65: 9-15.

Morse, J. M., Barrett, M., Mayan, M., Olson, K., and Spiers, J. 2002. Verification strategies for establishing reliability and validity in qualitative research. Int. J. Qual. Methods. 1: 13-22. doi: $10.1177 / 160940690200100202$

Mullan, B., and Wong, C. 2010. Using the theory of planned behaviour to design a food hygiene intervention. Food Cont. 21: 1524-1529. doi: 10.1016/j.foodcont.2010.04.026

Mullan, B., Wong, C., Todd, J., Davis, E., and Kothe, E. J. 2015. Food hygiene knowledge in adolescents and young adults. Br. Food J. 117: 50-61. doi: 10.1108/BFJ-03-2013-0060

Neil, K. P., Biggerstaff, G., MacDonald, J. K., Trees, E., Medus, C., Musser, K. A., Stroika, S. G., Zink, D., and Sotir, M. J. 2012. A novel vehicle for transmission of Escherichia coli 0157:H7 to humans: Multistate outbreak of E. coli O157:H7 infections associated with consumption of ready-to-bake commercial prepackaged cookie dough - United States, 2009. Clin. Infect. Dis. 54: 511-518. doi: $10.1093 / \mathrm{cid} / \mathrm{cir} 831$

Nesbitt, A., Majowicz, S., Finley, R., Marshall, B., Pollari, F., Sargeant, J., Ribble, C., Wilson, J., and Sittler, N. 2009. High-risk food consumption and food safety practices in a Canadian community. J. Food Prot. 72: 2575-2586. doi: 10.4315/0362-028X-72.12.2575

Oliver, D. G., Serovich, J. M., and Mason, T. L. 2005. Constraints and opportunities with interview Transcription: Towards reflection in qualitative research. Soc. Forces. 84: 1273-1289. doi: 10.1353/ sof.2006.0023

Patil, S. R., Cates, S., and Morales, R. 2005. Consumer food safety knowledge, practices, and demographic differences: Findings from a meta-analysis. J. Food Prot. 68(9): 1884-1894. doi: 10.4315/0362-028X-68.9.1884
Pedigo, A. S., Richards, J. K., Saxton, A. M., D’Sousa, D. H., and Draughon, F. A. 2009. Characterization of food safety knowledge, attitudes, and behaviors of adolescents in East Tennessee. Food Protection Trends. 29(10): 626-641.

Quick, V., Corda, W. K., Chamberlin, B., Schaffner, D. W., and Byrd-Bredbenner, C. 2013. Ninja kitchen to the rescue: Evaluation of a food safety education game for middle school youth. Br. Food J. 115: 686-699. doi: 10.1108/00070701311331481

Redmond, E. C., and Griffith, C. J. 2004. Consumer perceptions of food safety risk, control and responsibility. Appetite. 43: 309-313. doi: 10.1016/j.appet.2004.05.003

Richards, J., Skolits, G., Burney, J., Pedigo, A., and Draughon, F. 2008. Validation of an interdisciplinary food safety curriculum targeted at middle school students and correlated to state educational standards. J. Food Sci. Educ. 7(3): 54-61. doi: 10.1111/j.1541-4329.2008.00051.x

Sanlier, N. 2009. The knowledge and practice of food safety by young and adult consumers. Food Cont. 20: 538-542. doi: 10.1016/j. foodcont.2008.08.006

Schafer, R. B., Schafer, E., Bultena, G. L., and Hoiberg, E. O. 1993. Food safety: An application of the health belief model. J. Nutr. Educ. 25(1): 17-24. doi: 10.1016/S0022-3182(12)80183-X

Shearer, A. E. H., Snider, O. S., and Kniel, K. E. 2014. Implementation and assessment of food safety educational materials for secondary and postsecondary education. J. Food Sci. Educ. 13: 4-11. doi: $10.1111 / 1541-4329.12017$

Slater, J. 2013. Is cooking dead? The state of home economics food and nutrition education in a Canadian province. Int. J. Consum. Stud. 37: 617-624. doi: 10.1111/ijcs.12042

Smith, A. R., Chein, J., and Steinberg, L. 2013. Impact of socioemotional context, brain development, and pubertal maturation on adolescent risk-taking. Horm. Behav. 64: 323-332. doi: 10.1016/j. yhbeh.2013.03.006

Turconi, G., Guarcello, M., Maccarini, L., Cignoli, R., Setti, S., Bazzano, R., and Roggi, C. 2008. Eating habits and behaviors, physical activity, nutritional and food safety knowledge and beliefs in an adolescent Italian population. J. Am. Coll. Nutr. 27: 31-43. doi: 10.1080/07315724.2008.10719672

Usalcas, J. 2005. Youth and the labour market. Perspectives on labour and income, Statistics Canada. Available at: http://www.statcan.gc.ca/ pub/75-001-x/11105/8840-eng.htm [accessed 01 December 2015].

Yarrow, L. V., Remig, M., and Higgins, M. M. 2009. Food safety educational intervention. positively influences college students' food safety attitudes, beliefs, knowledge, and self-reported practices. J. Environ. Health. 71:30-35. 